\title{
KEdAULATAN SUMBER dAYA ALAM dI INdONESIA SEBAGAI AKTUALISASI NILAI-NILAI PANCASILA
}

\author{
I Gusti Ayu Ketut Rachmi Handayani \\ Fakultas Hukum UniversitasSebelas Maret \\ e-mail: ayu_igk@yahoo.com
}

\begin{abstract}
Exploitation of natural resources which is the utilization of natural resources unwisely led to the decline of natural resources both quantity and quality and will eventually run out. consistency, relevance, and contextualization of Pancasila is always needed by Indonesian people who are continuously developing according to world development. The realization of the expectation will make Pancasila able to play a role: internally, it functions as a glue of unity and union of Indonesian people and directs nation struggle towards its ideals. Externally, it functions as a nation identity so that Indonesian people are different from other people. This research used doctrinal methode. The source of data are secondary data.
\end{abstract}

Keywords: Sovereignty, natural resources, Indonesia, actualization, the values of Pancasila.

\begin{abstract}
Abstrak
Pengurasan sumber daya alam yang merupakan pemanfaatan sumber daya alam secara tidak bijaksana menyebabkan sumber daya alam tersebut menurun baik kualitasnya maupun kuantitasnya dan pada akhirnya akan habis. Konsistensi, relevansi dan kontekstualisasi Pancasila selalu dibutuhkan oleh orang-orang Indonesia yang terus menerus berkembang sesuai dengan perkembangan dunia. Realisasi harapan akan membuat Pancasila mampu memainkan peran: internal, berfungsi sebagai perekat persatuan dan kesatuan Bangsa Indonesia dan mengarahkan perjuangan bangsa menuju cita-citanya. Secara eksternal, berfungsi sebagai identitas Bangsa Indonesia sehingga masyarakat Indonesia berbeda dengan masyarakat lain. Penelitian ini menggunakan metode doktrinal. Sumber data yang digunakan adalah sumber data sekunder.
\end{abstract}

Kata Kunci: Kedaulatan, sumber daya alam, Indonesia, aktualisasi, nilai-nilai Pancasila.

\section{A. Pendahuluan}

Suatu pilar yang sangat esensial dalam suatu Negara adalah kedaulatan dalam Negara. Kedaulatan Negara dalam sila-sila Pancasila adalah terumuskan dalam kerakyatan yang dipimpin oleh hikmat kebijaksanaan dalam permusyawaratan perwakilan, diikuti serta mewujudkan suatu keadilan sosial bagi seluruh rakyat Indonesia (Kaelan, 651: 2013). Pasal 1 ayat (2) UUD 1945 (amandemen) disebutkan bahwa kedaulatan berada di tangan rakyat dan dilaksanakan menurut Undang-Undang Dasar. One of the important principles of the rule of law is the principle of legality. The substance of the principle of legality requires that every action is the agency / administrative officer under the law. without basic law, the agency / state administration officials are not authorized to perform any act which may alter or affect the legal situation of the community. The principle of legality is closely related to the idea of democracy and the idea of the rule of law. Idea of democracy demand that any form of laws and decisions approved by the representatives of the people and the interests of the people as much as possible (Handayani, I Gusti Ayu, 2012).

Dari berbagai persoalan dalam negeri, persoalan sumber daya alam Indonesia merupakan persoalan yang prioritas. Sumber daya alam tidak hanya secara kuantitas mengalami krisis tetapi juga secara kualitas mengalami kekritisan. Konflik di bidang Sumber Daya Alam adalah salah satu permasalahan besar di Indonesia Pasca-Reformasi. Sepanjang tahun 2013 saja, telah terjadi 232 konflik Sumber Daya Alam di 98 kabupaten kota di 22 provinsi. Pada setiap konflik ini selalu yang diiring dengan jatuhnya korban yang sebagian besar dari kalangan kaum tani. Dari sebanyak 232 konflik Sumber Daya Alam yang melibatkan petani ini, 69 persen di antaranya dengan korporasi (swasta), Perhutani 13 persen, taman nasional 9 persen, pemerintah daerah 3 persen, instansi lain 1 persen dan sisa 5 persen lainnya tidak dijelaskan oleh 
Kompas (Kompas, 16/02/2013). Buruknya sistem pengelolaan sumber daya alam memaksa negeri ini harus mengimpor minyak dan sumber daya alam lainnya. Mengandalkan impor semakin mempertegas bahwa sumber daya alam Indonesia kian menipis. Membeli dan mendatangkan barang dari luar negeri, terlebih produk yang sebenarnya merupakan komoditas negeri sendiri, mengindikasikan sumber daya alam Indonesia berada dalam masalah besar. Bocornya kekayaan alam Indonesia mengakibatkan sumber daya alam Indonesia semakin langka dan menipis. Prabowo menyatakan bahwa kelangkaan sumber daya alam menjadi salah satu tantangan serius yang tengah dihadapi Indonesia. Pernyataan tersebut disampaikan Prabowo saat ia memberikan kuliah umum di Rajaratnam School of International Studies (RSIS) Nanyang Technological University (NTU) Singapore pada saat Kuliah umum dengan tema "Indonesia Facing the Future: challenges for the Next 20 Years yang berlangsung 1 Agustus 2012 (emirza Adi Syailendra, 2012).

\section{B. Metode Penelitian}

Metode Penelitian yang digunakan dalam penelitian ini adalah penelitian normatif. Dalam konsep normatif hukum adalah norma, baik yang di identikkan dengan keadilan yang harus diwujudkan (ius constituendum), ataupun norma yang telah terwujudkan sebagai perintah yang eksplisit dan secara positif telah terumus jelas (ius constitutum) untuk menjamin kepastiannya dan juga yang berupa norma yang merupakan produk dari seorang hakim (judgements) pada waktu hakim itu memutuskan suatu perkara dengan memperhatikan terwujudnya kemanfaatan dan kemaslahatan bagi para pihak yang berperkara. Karena setiap norma baik yang berupa asas normal, keadilan ataupun yang telah dipositifkan sebagai hukum perundang-undangan maupun judgmade selalu eksis sebagai bagian dari suatu sistem doktrin atau ajaran yaitu ajaran tentang bagaimana hukum harus ditemukan atau dicipta untuk menyelesaikan suatu perkara, maka setiap penelitian hukum yang mendasarkan hukum sebagi norma disebut sebagi penelitian normatif yang doktrinal (Vide, Burhan dalam Setiono, 2002).

\section{Hasil Penelitian dan Pembahasan}

\section{Pengelolaan Sumber daya Alam}

There is rapidly emerging consciousness that the unresolved issues of environmental sustainability will produce severe adverse consequences if further ignored. The worst of the ecological problems, even at this point, may not be any longer remedied at acceptable costs (Richard Falk, 2009). Sumber daya alam yang dimiliki suatu Negara bagai pisau bermata dua. Di satu sisi ia akan mendatangkan banyak manfaat bagi rakyat jika dikelola dengan tepat. Di sisi lain, sumber daya alam justru akan merugikan Negara dan menyengsarakan rakyat jika berada di tangan yang tidak tepat. Oleh karena itu muncul istilah "the resource curse" atau kutukan sumber daya alam terkait pera Negara dalam mengelola sumber daya alam. Istilah kutukan sumber daya alam lahir karena banyak Negara yang sebenarnya kaya akan sumber daya alam namun gagal dalam mengambil manfaat dari berkah kekayaan alam yang mereka miliki. Akhirnya bukannya Negara tersebut meraih kemakmuran dan kesejahteraan, namun menjadi miskin (George Soros dalam Macartan Humphreys, 2007). Two of the three contributions examine justice considerations in the context of access to water and genetically modified resources, whereas the third contribution examines the gendered aspects of environmental law and justice with particular focus on access to natural resources (Jonas ebbesson, 2009).

Garret Hardin dalam karya tulisnya "The Tragedy of the commons" melihat bahwa alasan-alasan ekonomi yang sering kali menggerakkan perilaku manusia atau kepuusan-keputusan yang diambil oleh manusia secara perorangan maupun dalam kelompok, terutama dalam hubungannya dengan pemanfaatan common property. Common property adalah sumber-sumber daya alam yang tidak dapat menjadi hak perorangan, tetapi setiap orang dapat menggunakan atau memanfaatkannya untuk kepentingan masing-masing. Adanya kebebasan untuk mengeksploitasi sumber daya alam akan membawa kehancuran bagi masyarakat. Keadaan inilah yang oleh Hardin disebut dengan tragedy of the common (Takdir Rahmadi, 2012).

\section{Hak Menguasai Negara}

Indonesia sebagai Negara berdasarkan hukum, termasuk kategori Negara penganut hukum modern. Konsepsi Negara hukum modern secara konstitusi dapat dirujuk pada rumusan tujuan Negara yaitu: melindungi segenap bangsa Indonesia dan seluruh tumpah darah Indonesia, memajukan 
kesejahteraan umum, mencerdaskan kehidupan bangsa serta mewujudkan keadilan sosial. Normatif tujuan Negara tersebut, khususnya memajukan kesejahteraan umum dan mewujudkan keadilan sosial antara lain termuat di dalam Pasal 33 UUD 1945. Pasal 33 UUD 1945 sebagai dasar Hak Menguasai Negara mengatur tentang dasar sistem perekonomian dan kegiatan perekonomian yang dikehendaki dalam Negara Indonesia, tetapi Pasal 33 bukan sebagai sesuatu yang berdiri sendiri, namun berkaitan dengan kesejahteraan sosial. Berdasarkan pemikiran yang demikian, maka upaya memahami Pasal 33 tidak terlepas dari dasar pemikiran tentang kesejahteraan sosial. Atas dasar hal itu tujuan Hak menguasai Negara atas sumber daya alam adalah keadilan sosial dan sebesarbesarnya kemakmuran rakyat (Abrar Saleng, 2004). Dikuasai oleh Negara mempunyai padanan arti negara menguasai atau penguasaan Negara. Dalam ilmu Negara asal usul kekuasaan Negara kerap dihubungkan dengan teori kedaulatan (sovereignty) sebab dikaitkan dengan soal siapa yang berdaulat atau memegang kekuasaan dalam suatu Negara. Secara teoritik, kekuasaan Negara atas sumber daya alam bersumber dari rakyat yang dikenali sebagai hak bangsa. Negara dipandang sebagai territorial publieke rechtsgemeenschap van overhead en onderdanen, yang memiliki karakter sebagai suatu lembaga masyarakat hukum, sehingga kepadanya diberikan bidang kuasa atau kekuasaan untuk mengatur, mengurus dan memelihara (mengawasi) pemanfaatan seluruh potensi sumber daya alam (natural resources) yang ada dalam wilayahnya secara intern. Dalam kaitannya dengan hak penguasaan Negara atas sumber daya maka obyek kekuasaan Negara yang relevan ialah kekayaan (things) menurut Montesquieu dan benda-benda (obyek kekayaan) menurut Roscoe Pound karena keda-duanya merupakan sumber perekonomian Negara dan pokok-pokok kemakmuran rakyat. Menurut Bertrand Russel dalam suatu negara, penguasaan terhadap bidang ekonomi tergantung dan ditentukan oleh hukum Negara (Bertrand Russel, 1988).

\section{Negara Hukum Kesejahteraan (Welfare State)}

Pada umumnya Negara yang menganut faham kesejahteraan modern (modern walfare) juga merupakan negara hukum modern atau negara hukum dalam arti substansi atau faham negara hukum kesejahteraan (verzorgingsstaat). Teori negara hukum kesejahteraan merupakan perpaduan antara konsep negara hukum dan negara kesejahteraan. Menurut Burkens, sebagaimana dikutip Aminuddin (Aminuddin, 1999), Negara hukum (rechstaat) ialah Negara yang menempatkan hukum sebagai dasar kekuasaannnya dan penyelenggaraan kekuasaan tersebut dalam segala wujudnya dilakukan di bawah kekuasaan hukum. Sedangkan konsep Negara kesejahteraan, menurut Bagir Manan (Bagir Manan, 1996) ialah negara atau pemerintah tidak sematamata sebagai penjaga keamanan atau ketertiban masyarakat, tetapi pemikul utama tanggung jawab mewujudkan keadilan sosial, kesejahteraan umum dan sebesar-besarnya kemakmuran rakyat. Negara tidak dipandang lagi sebagai alat kekuasaan (instrument of power) semata-mata, tetapi mulai dipandang sebagai alat perkhidmatan (an agency of services). Faham yang pragmatik ini melahirkan konsepsi Negara kesejahteraan (welfare state) atau Negara hukum modern atau negara hukum substansi yang cirricirinya sebagai berikut:

a. Dalam Negara hukum kesejahteraan yang diutamakan adalah terjaminnya hak-hak asasi sosial ekonomi rakyat.

b. Pertimbangan-pertimbangan efisiensi dan manajemen lebih diutamakan disbanding pembagian kekuasaan yang berorientasi politis, sehingga peranan eksekutif lebih besar daripada legislatif.

c. Hak milik tidak bersifat mutlak.

d. Negara tidak hanya menjaga ketertiban dan keamanan atau sekedar penjaga malam (nachtwakerstaat), tetapi Negara turut serta dalam usaha-usaha sosial maupun ekonomi.

e. Kaidah-kaidah hukum administrasi semakin banyak mengatur sosial ekonomi dan membebankan kewajiban tertentu kepada warga negara.

f. Peranan hukum publik condong mendesak hukum privat sebagai konsekuensi semakin luasnya peranan Negara.

g. Lebih bersifat Negara hukum substantif yang mengutamakan keadilan sosial yang substantif pula.

Berdasarkan ciri-ciri di atas menempatkan peranan Negara pada posisi yang kuat dan 
besar dalam menciptakan kesejahteraan umum (public welfare) dan keadilan sosial (social justice). Konsepsi Negara yang demikian disebut Negara sebagai Negara menyelenggarakan kesejahteraan umum (bestuurszorg) (S.F. Marbun, 2003).

Konsep Negara hukum modern selain mengharuskan setiap tindakan Negara/ pemerintahan berdasarkan atas hukum, juga Negara/pemerintahan diserahi pula peran, tugas dan tanggung jawab yang luas untuk kesejahteraan masyarakat. Dari berbagai konsepsi Negara hukum modern menurut Bagir Manan (Bagir Manan, 1994) pada pokoknya memuat tiga aspek utama yaitu aspek politik, konsep hokum itu sendiri dan aspek sosial ekonomi.

\section{Teori Keadilan John Rawls}

Satu masalah yang menetap dalam perdebatan tentang keadilan sosial adalah cara melakukan distribusi sumber-sumber daya sedemikian rupa sehingga kemerataan dapat dicapai tetapi tanpa melanggar hak individual. Dalam terminology filsafat politik, masalah itu adalah cara mendamaikan liberty dan equality, dan mengangkatnya ke dalam konsepsi keadilan yang utuh. Salah satu upaya akademis yang ditunjukkan untuk mengatasi masalah ini dilakukan oleh John Rawls melalui teori Justice as Fairness. Rawls berargumen bahwa liberty dan equality dapat dipadukan dalam satu prinsip keadilan yaitu setiap orang memiliki hak yang sama terhadap kebebasan asasi. Apabila terjadi ketidakadilan, kaum yang tertinggal harus diuntungkan olehnya. Inilah prinsip yang harus tertanam di dalam institusi sosial apabila keadilan sosial hendak sungguhsungguh diwujudkan menurut pendapat Rawls Justice is the first virtue of social institutions, as truth is of systems of thought (C. Kukathas and P. Petit, 1990).

Ada beberapa basic assumption agar masyarakat bekerjasama dalam kondisi fair. Pertama, anggota masyarakat tidak memandang bahwa tatanan sosial masyarakat tidak berubah. Masyarakat harus menuju keadilan, sehingga masyarakat terbuka pada perubahan, terutama perubahan structural sosial. Kedua, kerjasama dibedakan dengan aktivitas yang terkoordinasi. Hal ini dapat dilihat dari hal-hal sebagai berikut:

a. Bentuk kerjasama selalu berpijak pada keadilan, sedangkan coordinated activity berpijak pada efektivitas/efisiensi. b. Kerjasama aturan dibuat untuk mengatur anggota-anggotanya (mengikat, mengatur kepentingan anggota) sedangkan dalam coordinated activity, aturan dibuat untuk kepentingan yang membuat aturan.

c. Dalam kerja sama harus sah secara public (harus disepakati oleh partisipan), sedangkan dalam coordinated activity, tidak ada organisasi dan aturan tidak harus sah secara publik.

Ketiga, gagasan kerjasama yang fair mengandaikan kebaikan dan keuntungan partisipan (partisipan mempunyai gagasan sendiri dan bertemu dengan gagasan lainnya dengan cara rasionalitas) (J. Rawls, 1985).

\section{Kedaulatan Negara}

Dalam UUD 1945 hasil amandemen disebutkan pada Pasal 1 ayat (2) bahwa kedaulatan berada di tangan rakyat dan dilaksanakan menurut Undang-Undang Dasar. Oleh karena itu dalam suatu Negara dalam menerapkan teori trias politica harus menempatkan Welfare State sebagai landasan operasional pelaksanaan dan penyelenggaraan Negara (Budiardjo, 1981). Negara harus menempatkan tujuan Negara sebagi Negara hokum material sebagai arah yang utama yaitu memajukan kesejahteraan umum dan mencerdaskan kehidupan bangsa. Kenichi Ohmae dalam bukunya The End of Nation State: The Rise of Regional Economics (Kenichi Ohmae, 1995) mengatakan bahwa Negara-negara bangsa (termasuk Negara Indonesia) di era global dewasa ini akan mendapat tekanan yang hebat dari kekuatan kapitalisme dunia dengan model ekonomi regionalnya, dan bukannya tidak mungkin jikalau Negara bangsa tidak memiliki prinsip dan ketahanan yang memadai maka akan membawa kehancuran Negara-negara bangsa. Dalam pelaksanaan system kenegaraan Indonesia diwujudkanlah suatu Negara hokum (rechtsstaats) dengan sistem kekuasaan di tangan rakyat, maka diterapkanlah sistem demokrasi, untuk mewujudkan suatu kesejahteraan yang berkeadilan (keadilan sosial bagi seluruh rakyat Indonesia) (Kaelan, 2013).

Pasal 1 ayat (3) UUD 1945 hasil amandemen mengatur bahwa Negara Indonesia adalah Negara Hukum. Artinya bahwa Negara dibangun dan dilaksanakan berdasarkan suatu Undang-Undang 
Dasar Negara. Selain itu nampak dalam penjabaran pasal-pasal UUD 1945 menganut sistem demokrasi. Secara filosofis sistem demokrasidijabarkan dan dikembangkan di Indonesia berdasarkan core philosophy bangsa Indonesia yang merupakan kesepakatan bersama yaitu nilai-nilai Pancasila. Negara tidak dapat dilepaskan dengan tanggung jawabnya untuk meningkatkan kesejahteraan sosial. Negara bergeser dari Negara hokum formal ke Negara hukum material yang secara aktif harus melaksanakan upaya-upaya untuk membangun dan mewujudkan kesejahteraan masyarakat dengan cara mengatur kehidupan soial ekonomi (Assidiqie, 2005).

\section{Nilai-Nilai Pancasila}

Pancasila sebagai dasar filsafat Negara Indonesia mengandung konsekuensi setiap aspek penyelenggaraan Negara dan semua sikap dan tingkah laku bansa Indonesia dalam bermasyarakat, berbangsa dan bernegara harus berdasrkan pada nilai-nilai Pancasila. Untuk menjaga konsistensi dalam mengaktualisasikan nilai Pancasila ke dalam praktik hidup berbangsa dan bernegara, maka perlu Pancasila formal yang abstrak-umumuniversal itu ditransformasikan menjadi rumusan Pancasila yang umum kolektif, dan bahkan menjadi Pancasila yang khusus individual (Suwarno, 1993: 108). Artinya, Pancasila menjadi sifat-sifat dari subjek kelompok dan individual, sehingga menjiwai semua tingkah laku dalam lingkungan praksisnya dalam bidang kenegaraan, politik, dan pribadi. Masalah aktualisasi nilai-nilai dasar ideologi Pancasila ke dalam kehidupan praksis kemasyarakatan dan kenegaraan bukanlah masalah yang sederhana. Soedjati Djiwandono (1995: 2-3) mensinyalir, bahwa masih terdapat beberapa kekeliruan yang mendasar dalam cara orang memahami dan menghayati Negara Pancasila dalam berbagai seginya. Kiranya tidak tepat membuat "sakral" dan taboo berbagai konsep dan pengertian, seakan-akan sudah jelas betul dan pasti benar, tuntas dan sempurna, sehingga tidak boleh dipersoalkan lagi.

Sikap seperti itu membuat berbagai konsep dan pengertian menjadi statik, kaku dan tidak berkembang, dan mengandung resiko ketinggalan zaman, meskipun mungkin benar bahwa beberapa prinsip dasar memang mempunyai nilai yang tetap dan abadi. Belum teraktualisasinya nilai dasar Pancasila secara konsisten dalam tataran praksis perlu terus menerus diadakan perubahan, baik dalam arti konseptual maupun operasional. Banyak hal harus ditinjau kembali dan dikaji ulang. Beberapa mungkin perlu dirubah, beberapa lagi mungkin perlu dikembangkan lebih lanjut dan dijelaskan atau diperjelas, dan beberapa lagi mungkin perlu ditinggalkan. Soerjanto Poespowardojo (1989: 14) menjelaskan, bahwa dinamika yang ada pada aktualisasi Pancasila memungkinkan bahwa Pancasila juga tampil sebagai alternatif untuk melandasi tata kehidupan internasional, baik untuk memberikan orientasi kepada negara-negara berkembang pada khususnya, maupun mewarnai pola komunikasi antar negara pada umumnya.

\section{Kasus Pengelolaan Sumber daya Alam di Indonesia}

Setiap Negara memiliki permasalahan lingkungan hidup yang berbeda. Namun secara umum ada permasalahan lingkungan hidup di Negara sedang berkembang seperti halnya Indonesia, memiliki masalah dalam pemanfaatan sumberdaya alam yang melebihi daya recovery-nya. Disamping itu permasalahan lainnya adalah pemanfaatan lingkungan yang melebihi daya dukungnya (Chafid Fandeli, 2004).

Beberapa kasus yang terjadi dan dapat dijadikan contoh antara lain: Kerusakan hutan yang mencapai 43 juta hektar hanya dalam tempo 20 tahun (World Resource, 2005) bisa jadi "bergandengan tangan" dengan kegagalan pemerintah menggunakan instrumen kebijakan publik, termasuk mengeluarkan perizinan dan membuat kontrak yang berkaitan dengan pengeksploitasian hutan. Belum terhitung kontrak lisensi paten di bidang obat-obatan, pertanian, informasi pengetahuan, dan teknologi yang berpotensi mengancam kepentingan masyarakat dalam memenuhi hak-hak fundamentalnya. Kasus semburan lumpur panas yang diakibatkan kelalaian Lapindo Brantas kini telah merenggut hakhak fundamental warga. Tidak kurang dari 13 ribu orang (Economist, 5 Oktober 2006) harus mengungsi karena kehilangan rumah, lingkungan hidup yang normal, dan pekerjaan, yang berimplikasi pada pemenuhan hak-hak fundamental lain, seperti hak atas pangan, kesehatan, dan pendidikan (Pasal 28 dan 31 UUD 1945). Tragedi Lapindo ini hanyalah salah satu dari sekian banyak tragedi yang menimpa masyarakat akibat ulah kontraktor/ 
pengusaha yang mengeksploitasi haknya berdasarkan prinsip kebebasan berkontrak secara absolut. Sejak terjadinya krisis ekonomi yang melanda Indonesia pada tahun 1997 telah berkembang menjadi krisis multi dimensional. Krisis ini secara langsung atau tidak langsung juga berpengaruh pada lingkungan hidup. Setiap pengeksploitasian hak (baik individu maupun korporasi) yang bertentangan dengan hak-hak fundamental tersebut adalah inkonstitusional.

Di dalam pembukaan UUD 1945 telah disebutkan bahwa salah dasar dan tujan pembentukan Negara Indonesia adalah sebagai berikut: "Kemudian daripada itu untuk membentuk suatu pemerintah negara Indonesia yang melindungi segenap bangsa Indonesia dan seluruh tumpah darah Indonesia dan untuk memajukan kesejahteraan umum, mencerdaskan kehidupan bangsa, dan ikut melaksanakan ketertiban dunia yang berdasarkan kemerdekaan, perdamaian abadi dan keadilan sosial, maka disusunlah kemerdekaan kebangsaan Indonesia itu dalam suatu Undang-Undang Dasar negara Indonesia, yang terbentuk dalam suatu susunan negara Republik Indonesia yang berkedaulatan rakyat dengan berdasar kepada :

1. Ketuhanan yang Maha esa,

2. Kemanusiaan yang adil dan beradab,

3. Persatuan Indonesia, dan

4. Kerakyatan yang dipimpin oleh hikmat kebijaksanaan dalam permusyawaratan/ perwakilan,

5. Keadilan sosial bagi seluruh Rakyat Indonesia.

Pasal 33 UUD 1945 (dan perubahannya) memberikan kewenangan negara untuk menguasai dan mengelola kekayaan alam di seluruh Indonesia, namun peruntukannya adalah sebesar-besarnya untuk kepentingan rakyat. Berdasarkan konstitusi kita, di Indonesia, konsepsi kesejahteraan bersumber dari :

(1) Ketuhanan yang maha esa,

(2) Keadilan social,

(3) Keberadaban manusia dan

(4) Persatuan / keseimbangan seluruh Indonesia (antara daerah dan hubungan pusat-daerah)

Pendiri Negara kita, menggunakan pilar keluarga untuk menggabarkan sifat khas kesejahteraan social di Indonesia. Sampai saat ini, pembangunan kesejahteraan sosial sudah maju dilakukan oleh pemerintah bersama masyaraat Indonesia. Namun demikian, beberapa masalah mendasar bidang kesejahteraan sosial, masih belum terselesakan secara tuntas.

\section{d. Simpulan}

Pancasila sebagai dasar filsafat Negara Indonesia mengandung konsekuensi setiap aspek penyelenggaraan Negara dan semua sikap dan tingkah laku bangsa Indonesia dalam bermasyarakat, ber bangsa dan bernegara harus berdasarkan pada nilai-nilai Pancasila. Bahwa nilai-nilai Pancasila yang bersumber pada silasila Pancasila adalah merupakan nilai yang universal. Nilai-nilai tersebut perlu dijabarkan lebih lanjut menjadi norma-norma kenegaraan maupun norma-norma moral untuk dilaksanakan dan diaktualisasikan oleh setiap warga Negara Indonesia. Oleh karena itu selain sila-sila Pancasila merupakan suatu sumber nilai bagi tertib hukum di Indonesia, sekaligus juga merupakan suatu sumber norma moral bagi suatu pelaksanaan hukum, penyelenggaraan kenegaraan di Indonesia dalam mewujudkan kedaulatan sumber daya alam. Dinamika dalam mengaktualisasikan nilai Pancasila ke dalam kehidupan bermasyarakat, berbangsa, dan benegara harus terus ditanamkan mulai di keluarga, sekolah, kampus, instansi pemerintah, swasta, LSM, organisasi sosial, masyarakata dan komunitas-komunitas di masyarakat dalam fungsinya memberikan pedoman bagi pengambilan kebijaksanaan dan pemecahan masalah dalam kehidupan berbangsa dan bernegara.

\section{E. Saran}

Akselerasi yang diperlukan dalam mengaktualisasikan Pancasila dalam mewujudkan kedaulatan sumber daya alam di Indonesia selain pendorong lahir bathin, masih terdapat suatu keadaan yang sangat diperlukan yaitu kesadaran akan wajib bagi setiap warga Negara Indonesia dan pemerintah. Rasa wajib yang telah tertanam dalam diri manusia Indonesia dan meresap dalam hati sanubari sebagai suatu kesadaran, sehingga setiap manusia Indonesia dalam keadaan bersedia untuk melaksanakan Pancasila terutama dalam mewujudkan kedaulatan sumber daya alam sebaga suatu local wisdom. Akselerasi tersebut perlu dimantapkan dalam berbagai situasi dan keadaan yang terlembagakan di masyarakat dan pemerintah secara terintegrasi.

Kedaulatan Sumber Daya Alam di Indonesia .... 55 


\section{daftar Pustaka}

Abrar Saleng. 2004. hukum Pertambangan. yogyakarta: UII Press.

Aminuddin. 1999. Privatisasi BUMN Persero. Disertasi. Surabaya: PPS UNAIR.

Bagir Manan. 1994. hubungan Antara Pusat dan Daerah Menurut UUD 1945. Jakarta: Pustaka Sinar Harapan.

1996. Politik Perundang-undangan Dalam Rangka Mengantisipasi Liberalisasi Perekonomian. Bandar Lampung: FH-UNILA.

C. Kukathas and P. Petit. 1990. Rawls: A Theory of Justice and Its critics. Oxford: Polity.

Chafid Fandeli. 2007. Analisis Mengenai Dampak Lingkungan Prinsip Dasar Dalam Pembangunan. yogyakarta: Penerbit Liberty.

ebbesson, Jonas. 2009. Introduction: Dimensions of Justice in Environmental Law. Cambridge University Press.

Economist. 2006. 5 Oktober

emirza Adi Syailendra. 2012. Indonesia's Prabowo Subianto tests the water in Singapore. east Asia Forum, $6^{\text {th }}$ October 2012.

Handayani, I Gusti Ayu Ketut Rachmi, 2012. Implementation of Verdict of the Constitutional Court of The Republic of Indonesia Against Judicial Review Act No. 7 of 2004 on Water Resources in the ex Region Surakarta Indonesia, Journal of Law, Policy and Globalization, New york. USA.

Humphreys, Macartan dkk. 2007. Escaping The Resource curse: Berkelit dari Sumber Daya Alam (Terjemahan). The Samdhana Institute Bogor.

Jimly Assidiqie, 2005. Demokrasi dan hAM. Makalah pada Studium General The $1^{\text {st }}$ National Converence Corporate Forum for Community Development. Jakarta.

J. Rawls. 1985. Justice as Fairness Political Not Metaphysical. Philosophy and Public Affairs.

Kaelan. 2013. Negara Kebangsaan Pancasila. yogyakarta: Paradigma.

Kenichie, Ohmae. 1995. The End of Nation State: The Rise of Regional Economics. London: The Free Press.

Kompas. 2013. 16/02. Konflik Sumber Daya Alam Meluas di 22 Provinsi.

Muslim Mufti dan Didah Durrotun Naafisah. 2013. Teori-Teori Demokrasi. Bandung: Penerbit Pustaka Setia.

Richard Falk. 2009. The Second cycle of Ecological Urgency: An Environmental Justice Perspective. Cambridge University Press.

Russel, Bertrand. 1988. Kekuasaan Sebuah Analisis Sosial Baru. Jakarta: yayasan Obor Indonesia.

Setiono, 2005. Pemahaman Terhadap Metodologi Penelitian hukum. Surakarta: Penerbit UNS Pres.

S.F. Marbun. 2003. Peradilan Administrasi dan Upaya Administratif di Indonesia. Cetakan Kedua (Revisi). yogyakarta: UII Press.

Soerjanto Poespowardojo. 1989. Filsafat Pancasila. Jakarta: Gramedia.

Soedjati Djiwandono, J. 1995. Setengah Abad Negara Pancasila (Tinjauan Kritis ke Arah Pembaharuan. Jakarta: CSIS.

Suwarno, P.J. 1993. Pancasila Budaya Bangsa Indonesia. yogyakarta: Penerbit Kanisius.

Takdir Rahmadi. 2012. hukum Lingkungan di Indonesia. Jakarta: Rajawali Perss. 